\title{
Gjensyn med Auditorium 13
}

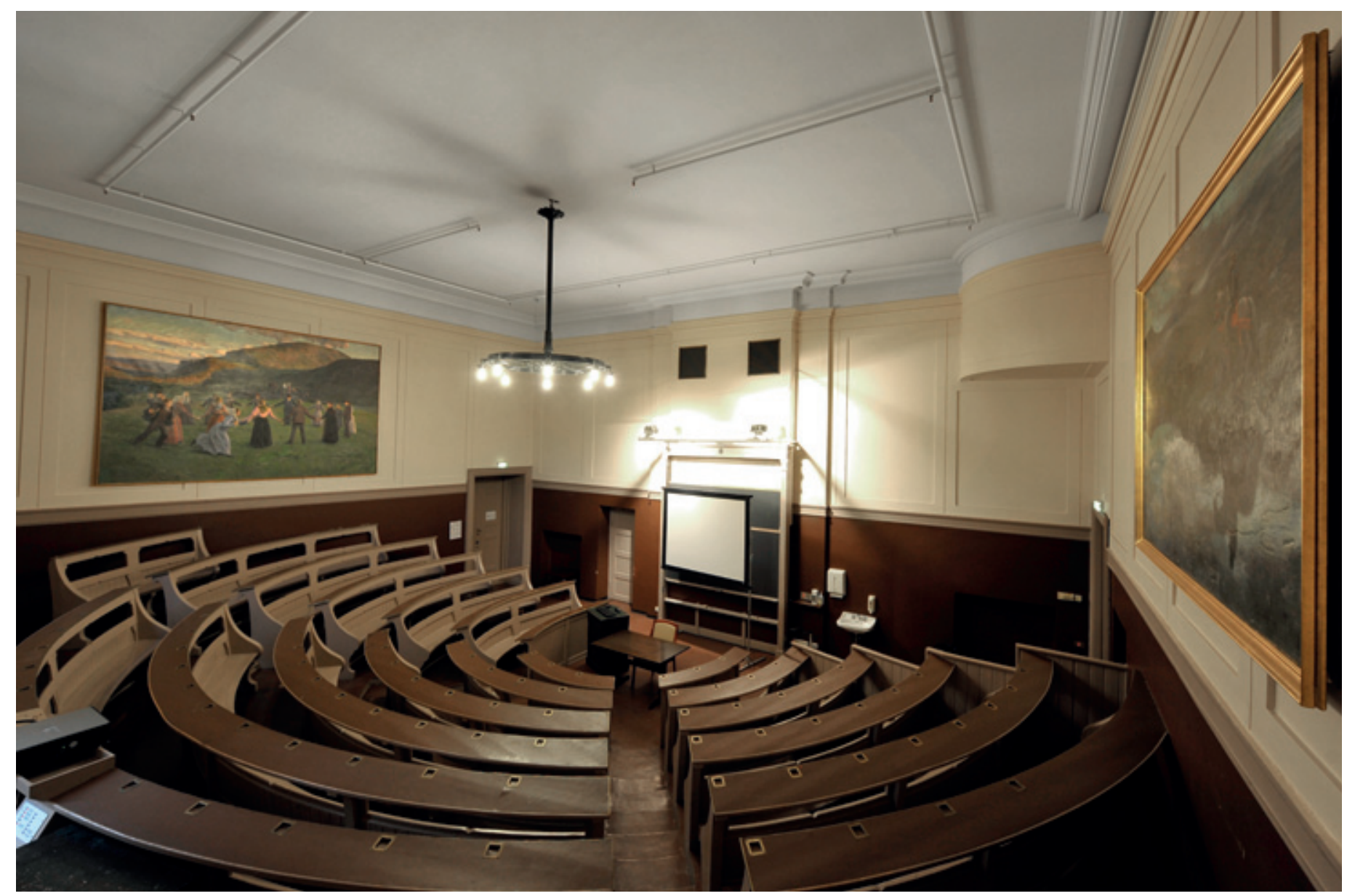

Foto Francesco Saggio/Universitetet i Oslo

Auditorium 13 i Domus Media angår mange norske leger - de som frem til 1980 begynte på medisinstudiet i Oslo. Det året ble den prekliniske undervisning flyttet til nye bygninger på Gaustad. Siden Universitetet i Oslo i år feirer 200-årsjubileum, er det nærliggende å komme med noen betraktninger om universitetskomplekset i Karl Johans gate, som var innflyttingsklart i 1852. For medisinerne innebar dette et nytt anatomisk institutt $i$ den østlige del av Domus Media etter flytting fra Anatomikammeret, den lave, gule bygningen på Christiania torv. Den står der fremdeles - vis-à-vis Legenes hus.

I Auditorium 13, dette særegne rommet med det halvmåneformede benkearrangementet, ble det holdt forelesninger i anatomi. Det var også åstedet for den krevende muntligeksamenen i makroskopisk og mikroskopisk anatomi høst og vår. Mange vil sikkert huske flere innredningsdetaljer. Spesielt sjar- merende er de firkantede messinghylsene nedfelt $\mathrm{i}$ benkene - til plassering av blekkhus! Over døren på utsiden kunne man i forgylt skrift lese den gamle pedagogiske regel «repetitio est mater studiorum».

Av respekt for fortiden har man kalt et av auditoriene i Domus Medica på Gaustad for Nye auditorium 13.

Auditorium 13 er overtatt av Det juridiske fakultet og ble oppusset i 1990-92 under veiledning av Byantikvaren og Riksantikvaren. Det er kun gjort minimale forandringer, vesentlig gjelder det fargevalget - man skiftet fra grønt til brunt på benker og dører. Gulvbelegget, i brun linoleum, er beholdt. Auditoriet er fredet.

\section{Jacob Klafstad}

jacobklafstad@tele2.no

Oslo
Jacob Klafstad (f. 1934) er cand.med.,

cand.odont. og spesialist i kjevekirurgi og har i 12 år hatt overordnet stilling i Hærens sanitet, Sjøforsvarets sanitet og Forsvarets sanitetsstab. Ingen oppgitte interessekonflikter.

Mottatt 30.1. 2011, første revisjon innsendt 18.3. 2011, godkjent 31.3. 2011. Medisinsk redaktør Erlend Hem. 